\title{
European Cultural Integration: Theories and Practices
}

\author{
Mehlika Özlem Ultan
}

\begin{abstract}
In the history of the European integration, there are many theories which have tried to explain the integration process. Each of them can focus on one or two important aspects of the integration. As usually known, the European Union is an organization which is based on an economic integration. Thus, most of the theories are related to this topic. Although some other theories are interested in political aspects of the integration, cultural integration is the least mentioned part of the process.

Within the context of globalization, cultural aspects have become more important. European Union countries are much more interested in Europeanization theories and also the characteristics of national societies. The purpose of this study is to discuss the integration theories which are related to cultural perspectives. After a literature review, the integration theories and the rhetoric that are used for explaining the cultural perspectives will be analyzed.
\end{abstract}

Index Terms-Cultural integration, european culture, integration theories, social constructivism.

\section{INTRODUCTION}

Since the beginning of the European Union, many integration theories have been put forward. When the origins of each theory have been investigated, it can be seen that each of them is grouped under some headings. These are; 'Explaining integration', 'Analyzing governance' and 'Constructing the European Union'. These groups are related to their impact on the integration process itself.

Federalism, Neo-functionalism, and Liberal Intergovernmentalism can be classified under the explaining integration theories. These theories try to find out how can the integration process be explained. New Institutionalism, Multilevel Governance, and Social Constructivism are the theories which try to analyze the governance and explore the nature of the integration. In 1980's and 1990's, the epistemological, ontological, and traditional approaches were questioned by the scholars. Thus, the Discursive Approaches and Gender Perspectives have symbolized the constructing the European Union theories [1].

All of these theories have different impacts on the integration process. Although the economic and political integration theories have been mostly analyzed by the scholars, the theories which have focused on the cultural integration are disregarded. This study tries to seek the effects of the theories on the European cultural integration. For this purpose, firstly the integration theories have been investigated and the most important theory that explains the cultural integration has been determined. Concerning the EU, neo-functionalism and the theory of intergovernmentalism can be seen two main theoretical perspectives on integration.

Manuscript received July 5, 2016; revised November 13, 2016

Mehlika Ozlem Ultan is with Kocaeli University, International Relations Department, Kocaeli/Turkey (e-mail: ozlemultan@gmail.com).
Federalism has some statements about cultural integration and identity in the European Union. But social constructivism is accepted as the most important theory which aims to explain the cultural integration. Within the context of this study, federalism and social constructivism will be analyzed both in terms of theory and practices.

\section{Cultural INTEgRATION OF THE EUROPEAN UNION}

The European integration process is very complicated. Through the enlargement processes, the European Union has gained more traditions, religions and more languages, which makes the creation of European identity more difficult and complex. Cultural integration of the European Union is generally disregarded by scholars. However, it should not be forgotten that although integration has firstly had an economic formation, the European citizens have mostly faced with its cultural sides. The European model shows that an ever closer union between people can be realized if it is based on shared values and common objectives.

Sharing a common culture helps to have a common understanding of the concepts such as human rights, democracy or rule of law. But, it is not static; it can constantly change because of the socialization process. Common culture and common beliefs are tried to be built over the years [2].

There are various International Relations theories which try to explain the European integration, but only a few of them are related to the cultural integration. Cultural integration of the European Union can be analyzed within the context of integration theories. This study will analyze federalism and social constructivism as theories which have mentioned about cultural integration.

\section{FEDERALISM}

Federalism can be accepted as the most controversial theory of the European integration. The transfer of authority issue has always been one of the problems of the Union has faced with. In order to understand the impact of federalism on the European Union cultural integration, first of all, federalism should be explained on a theoretical level.

\section{A. Federalism as a Theory}

According to the international relations scholars, federalism can be seen as a feature of a domestic political organization in the modern federal state [3]. Federalism is a heterogeneous concept, so there is no accepted definition of it [4]. The origin of federalism is the Latin term 'Foedus' which means the act of creating a covenant, or contract of a bargain. Over the years, it has evolved to a voluntary union of entities. There are various types of federalism, so its meaning and practice can change from situation to situation and from country to country which is being used. Federalism in Europe can be put into practice as 'ever closer union among the 
peoples of Europe'. It is difficult to bring together separate, sovereign, autonomous and territorial units in order to form a new kind of union. Thus, the European Union remains as a complex mixture of institutions and policies [1].

One of the founders of the European Union, Jean Monnet believed that 'the political strategy of small, concrete, economic steps would culminate in a federal Europe'. Altiero Spinelli who is the representative of modern federalism believed that the union would begin with political institutions and this would help the formation of a European constitution. Spinelli stated that Monnet's idea of Europe could not meet the realities of political Europe [1].

According to federalism, the purpose of the European Union is to support the integration of different entities without assimilating them. There is a need for finding the balance between shared rule and self-rule so that to be a unified entity and maintain diversity would be easier.

\section{B. Federalism in Practice}

Some of the scholars agree that the value and the purpose of the European Union can be meaningful with the effect of federalism. Federalists believed that after the Second World War, the only solution to prevent war is to constitute a unified entity. There was a need for a supranational government which would regulate the relations of states. And the European Union can be accepted as s unique type of federal system among states [5].

In the European Union, federalism has seen as the application of federal rules to the European integration process where the integration means the sense of coming together of previously separate or independent states in order to constitute a new entity [1]. The European Union is one of the closest examples of a federalist entity, but even the Union has not also been totally achieved to this aim [6].

A federal Europe means a voluntary union of citizens and states who share the aims of welfare, prosperity, and security. But this situation can be realized only if nation states preserve their cultures, identities, and interests. In sum, federalism is based the 'unity in diversity' [7].

There is a three-way model which tries to explain how federations arise:

1) A wish to counter a perceived threat which can be military, economic, or social,

2) A wish to be a part of a federation or territorial entity, in order to counter this threat,

3) A common cultural basis.

4) Having a common cultural basis is crucial for facilitating the decision to join a federation [2].

Although federalism played an important role in the early period of International Relations, as a European cultural integration theory, it cannot be sufficient to end the discussions that the EU is a federal entity or a confederation. In practice, the United States is the best example of a federation. But, the EU may never be a federal entity in terms of 'United States of Europe' [3].

\section{SOCIAL CONSTRUCTIVISM}

Social constructivism can be accepted as the most important theory which facilitates the explaining of European cultural integration. In order to understand its impact on the cultural integration, firstly it is needed to explain the theory itself and then it will be better to see its practices in the European Union.

\section{A. Social Constructivism as a Theory}

Social constructivism is an international relations theory which is recently imported into European Union studies [8]. International Relations theories have two categories, the former is 'rationalist', and the latter is 'reflectivist' theories. While rationalism tries to explain the world with empirical and rational assumptions, reflectivism is based on the events, not the empirical data [9]. Social Constructivism is not a part of these two categories. It arises from an idea which criticizes both the rationalist and reflectivist theories [6].

The constructivist theory underlines the significance of social construction and social interaction in international relations discipline [10]. Constructivism can be understood both a social construction of meaning and the construction of social reality. This process has two important sections. The first step aims to analyze the sociological changes in the social sciences. And the second step's purpose is to reconstruct the social reality according to the sociological changes [11].

In the history of international relations, Nicholas Onuf was accepted as the creator of the constructivist theory. He stated that the world in which we live is a 'world of our making' [12]. After Onuf, Alexander Wendt maintained his ideas. He believed that interests are not pre-given, they are socially constructed. How collective understandings emerge and how institutions constitute the identities and interests of actors are the main questions that constructivists are interested in. The constructivist theory has called itself as the best theory which can explain the European integration as a process. That is the reason why constructivists are predisposed to think about how humans interact in a way that produces structures. Social constructivism argues that identities such as 'European Citizenship' are constructed through the use of language, the development of ideas and the establishment of norms, so it can be said that identities are never fixed, they are generally constructed [6].

Social constructivism is a body of thought, a set of ideas and norms which have been constituted by some people at a particular time and place. If the ideas and norms change, the system itself will change itself too [13]. According to constructivism, states are not the sole units in the international system, the identity and interests of states have also an important impact on the historical processes [14]. Social constructivism aims to problematize the interests and identities of states. It defines the international structure in terms of a social structure of norms, laws, and rules. Social structures are defined as shared understandings, expectations, or knowledge. These shape the situation and the nature of the actors' relationships [15]. According to constructivists, epistemological and ontological issues are crucial and the world is a project which is always under construction [16].

\section{B. Social Constructivism in Practice}

After the signing of Amsterdam Treaty, social constructivism theory became more important in the European Union studies. Because of its situation between the Realist and Reflectivist approaches, it was seen a more useful tool for explaining the complex nature of the European Union [17]. According to constructivism, the social world is a world 
of human consciousness, of beliefs, of ideas, of languages, of discourses, and of understandings among human beings [13].

In practice, the policies and norms of the European Union have always been changed according to the internal and external factors like the Cold War, globalization, enlargement processes, and global threats. As a result of these structures, actors can re-establish their interests. So that European norms, ideas, and discourses can penetrate into the different national policies which constitute the EU [6].

Social constructivism underlines the importance of interaction between agents and structures. In the European Union studies, various authors have stated that EU institutions shape both the preferences and identities of individuals and also member states. European integration is accepted as a process, so the best explaining theory should be social constructivism [18]. It can offer a basis for analyzing a wide range of social ontologies, such as identity, community, and collective intentionality [19].

Social constructivism theory can be put into practice via identity formation and discourse. First of all, it should be analyzed the effects of constructivist theory on identity formation. This process can be seen in three categories:

1) Research of the nature of a potential European identity,

2) Research of the reconstruction of national identities according to the integration process,

3) If there is a plurality of national identities and cultures, in order to find out which is ideal identity, formation theories can be imported to the study of European integration [19].

Most of the constructivist scholars agree that identity is one of the main tenets of constructivism. Identities can change over time and across context. They are not given, they are produced [16]. The idea to create a 'common European identity' may be an important example of the constructivist impact on the cultural integration. Common European identity is a shared identity which is valuable in explaining European integration, European enlargement, and decision-making processes [20]. Chebakova states that constructivism both represents the importance of common identity, and reveals how institutionalizing norms collectively can result in a new institution [21].

Constructivist researches focus not only on identity formation but also on the effects of language and discourse. According to constructivists, discourse is crucial in order to understand institutional change and policy reforms [18]. The making of culture can be seen as a kind of meaningful movement or an operation that takes place in discourse [22]. The main tool for the institutionalization of norms is speech acts. They are used by the politicians to change realities and provide the meaning for action [21]. Language and discourse are constructivist norms and they offer insightful observations about the history and creation of many European Union institutions [23]. Language is the use of vocabulary which shapes the Euro-speak. Nearly all of the integration processes and enlargement procedures are dominated by speech acts. Creating a special language and discourse makes it easier to European cultural integration both in a broad and narrow sense. Discourse is also useful for understanding the diplomacy and negotiations of the European Union. The impact of language can be seen in every aspect of the Union such as processes of deliberation, bargaining, and negotiation of policies [19].
Besides identity formation and discourse, the role of ideas is also crucial for the European cultural integration. Constructivist research is related to the formation of ideas. The 'European idea' and the formation of this idea have contributed to the creation of European norms. When the importance of common beliefs, values and cultures are recognized, the role of epistemic communities, knowledge and ideas can be integrated into a constructivist European Union policy analysis [19].

The practice of the social constructivist theory can be seen in the securitization issues as well. As a nature of the securitization, discourse and speech acts are very crucial. In this process, security is treated as the outcome of a specific social event. The construction of security issues is determined by analyzing the 'securitizing speech-acts and discourses' through which threats become represented. These issues become 'securitized' and treated as security problems. The understanding of speech-acts is so influential in the improvement of constructivism in international relations. Constructivism determines security practices as specific kinds of social construction, and securitization process as a particular form of social accomplishment [24]. Migration to the European coasts and migration policies of the Union can be given as the best examples of the securitization issues of the European Union.

In contemporary Europe, the citizenship practice and policy have been in a period of change. Both the domestic political dynamics and the external factors are effective on this change. With the enlargement process, European organizations have begun to promote new forms of citizenship, revise understandings of national citizenship and the cultural rights of national and ethnic minorities [25].

\section{CONCLUSION}

Most of the researchers and scholars have interested in economic and political integration processes rather than cultural phases. Within the context of this study, an approach which focuses on cultural integration towards European integration process is examined. In order to understand the impacts of theories on the cultural integration processes; federalism and social constructivism are determined and analyzed. After a brief explanation of these theories, their practices were investigated.

Federalism underlines multicultural policy of the European Union, it does not argue to assimilate different cultures into European culture. Although federalism provides an important aspect of European integration, the impact of federalism on the cultural integration is not as clear as social constructivism. Constructivism uses federal theories in order to make a more persuasive analysis of the European integration. It determines the political practices, norms, ideas, cultures and their intersubjective meanings. Social constructivism, which is evolved from a critique of realism and liberalism, is a useful theory since it focuses on human practice and the mutual relationship between structures and institutions.

One of the most important fields of cultural integration is language. To speak the same language is accepted as a facilitating way of the integration process. And using the language via speech acts is another way of cultural 
integration. The integration of migrants and minorities in various European countries can be ensured by language, discourse, and speech acts. Constructivism generally focuses on the social aspects of the integration. Because of this situation, it is expected to be a leading theory on the analysis of cultural integration.

\section{REFERENCES}

[1] A. Wiener and T. Diez, European Integration Theory, Oxford: Oxford University Press, 2004.

[2] S. Dosenrode, "Federalism theory and neo-functionalism: Elements for an analytical framework," Perspectives on Federalism, vol. 2, no. 3, pp $1-28,2010$.

[3] R. Koslowski, "A constructivist approach to understanding the European Union as a federal polity," Journal of European Public Policy, vol. 6, no. 4, pp. 561-578, 1999.

[4] P. V. Maior, "The European Union as a federal polity? An input to an unfinished symphony," in Proc. the 21st World Congress of the International Political Science Association (IPSA), Santiago, Chile July 12-16, 2009, pp. 1-25.

[5] C. Hill and M. Smith, International Relations and the European Union, Oxford: Oxford University Press, 2005.

[6] B. Rosamond, "New theories of European integration," in European Union Politics, M. Cini, ed. First ed. Oxford: Oxford University Press, 2003, pp. 109-130.

[7] M. Burgess, "Federalism and Federation," in European Union Politics, M. Cini, ed. First ed. Oxford: Oxford University Press, 2003, pp. 65-79.

[8] E. Ç. Öztürk, "Identity, Foreign Policy and Reconciliation: An assessment of the national identity and bilateral relations within the context of constructivist theory," New Turkey, vol. 60, pp. 1-12, 2014.

[9] A. Heywood, Politics, 3rd ed. Palgrave Macmillan, 2007.

[10] H. S. Ertem, "A Constructivist Approach to the Identity and Security Relationship: "The Identity of the Security" and "The Security of the Identity," Security Strategies, vol. 8, no. 16, pp. 177-236, 2012.

[11] S. Guzzini, "A reconstruction of constructivism in international relations," European Journal of International Relations, vol. 6, no. 2, pp. 147-182, 2000.

[12] N. Onuf, World of our making, University of South Columbia Press, 1989.

[13] R. Jackson and G. Sørensen, Introduction to International Relations Theories and Approaches, Oxford: Oxford University Press, 2003.
[14] M. Tandoğan, "Konstrüktivizm (sosyal inşacılık) kuramı bağlamında afrika birliği," Insan ve Toplum Bilimleri Araştırmaları Dergisi, vol. 4 , no. 3, pp. 634-650, 2015

[15] A. Wendt, "Constructing international politics," International Security, vol. 20, no. 1, pp. 71-81, 1995.

[16] P. R. Viotti and M. V. Kauppi, International Relations Theory, New York: Pearson Education, 2010.

[17] T. Risse and A. Wiener, "Something rotten' and the social construction of social constructivism: A comment on comments," Journal of European Public Policy, vol. 6, no. 5, pp. 775-782, 1999.

[18] T. Christiansen, K. E. Jørgensen, and A. Wiener, "The social construction of Europe," Journal of European Public Policy, vol. 6, no. 4, pp. 528-544, 1999.

[19] M. A. Pollack, "International relations theory and European integration," Journal of Common Market Studies, vol. 39, no. 2, pp. 221-244, 2001.

[20] T. Risse, "Social constructivism and European integration," in European Integration Theory, A. Wiener, and T. Diez, ed. Oxford: Oxford University Press, 2004, pp.159-176.

[21] A. Chebakova, "Theorizing the EU as a global actor: A constructivist approach," The Maturing European Union - ECSA-Canada Biennial Conference Paper, 2008, pp. 1-16.

[22] J. Ifversen, "Europe and European culture - A conceptual analysis," European Societies, vol. 4, no. 1, pp. 1-26, 2002.

[23] T. Aalberts, "The future of sovereignty in multilevel governance Europe - A constructivist reading," Journal of Common Market Studies, vol. 42, no. 1, pp. 23-46, 2004.

[24] M. C. Williams, "Words, images, enemies: Securitization and international politics," International Studies Quarterly, vol. 47, pp. 511-531, 2003.

[25] J. T. Checkel, "Why comply? Social learning and European identity change," International Organization, vol. 55, no. 3, pp. 553-588, 2001.

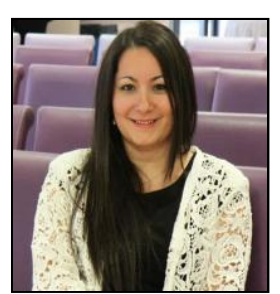

Mehlika Özlem Ultan was born in Istanbul, Turkey in 1984. She got her Ph.D. degree in the field of European Union from Istanbul University, Turkey, in 2015. She is currently working as a research assistant in the International Relations department at Kocaeli University, Turkey. Her research area is about the migration policy of the European Union, European identity, European culture, the European law, and the European institutions. Dr. Ultan wrote various articles and had publications in European Union studies, cultural integration, and migration policies. 